\title{
Human Rights and Central American Migrants in Mexico: A Judicial Perspective
}

\author{
Dra. Perla Barbosa Muñoz ${ }^{1} \&$ Jerjes Izcoatl Aguirre Ochoa ${ }^{2}$ \\ 1 Universidad Michoacana de San Nicolás de Hidalgo, School of Law, Universidad Michoacana, Morelia, \\ Michoacán, México \\ ${ }^{2}$ Universidad Michoacana de San Nicolás de Hidalgo, Institute of Economics, Morelia, Michoacán, México \\ Correspondence: Dra. Perla Barbosa Muñoz, School of Law, Universidad Michoacana, Morelia, Michoacán, \\ México. E-mail: perla_abm@hotmail.com
}

Received: August 10, 2013 Accepted: October 16, 2013 Online Published: June 25, 2014

doi:10.5539/ass.v10n13p263 URL: http://dx.doi.org/10.5539/ass.v10n13p263

\begin{abstract}
Central American immigrants in Mexico are particularly vulnerable and often invisible in the Mexican agenda of human rights. Each year, tens of thousands of men, women and children enter Mexico without legal permission as irregular migrants. More than nine out of ten are from Central America, especially from the countries of Guatemala, Honduras and El Salvador. This paper presents an analysis of the current situation of Central American migration in Mexico and the historical evolution of migration policy, as well as a study on the violation of human rights of Central American migrants in Mexico as past and current policy, and actions that have been generated and should be taken to ensure their protection.
\end{abstract}

Keywords: central American migration, immigrants, human rights, national commission of human rights, national institution of migration

\section{Introduction}

Central American immigration into Mexico has been a historical constant since the 1920's and its level has fluctuated during the twentieth century, increasing since 1990 with an important rise from the years 2000-2010. The majority of the Central American immigrants who arrive in Mexican territory do so in their journey toward the United States. Like many Mexicans, they seek the opportunity of work and a better life that is promised in the land of the north and has not been found in their own country.

Central American migrants in Mexico share the common denominator of being undocumented, which theorists describe as irregular migration. This state converts them into a population that is vulnerable to physical and psychological violations as well as of their human rights by Mexican authorities in particular. Violations occur among the same migrants, given the condition of uncertainty before the impossibility of being able to seek protection by the Mexican Authorities to safeguard their physical and emotional health confronting the fear of being deported.

The National Commission of Human Rights has figured as a principal promoter of respect forthe human rights of Central American migrants and has even emitted recommendations to responsible authorities. However, the amount of complaints presented before the Commission that have been shelved due to insufficient evidence is noteworthy. Nevertheless, due to the constitutional reforms of 2011, it is expected that the Commission will be able to generate more efficient actions to insure that the human rights of these immigrants and all people located in Mexico, whether they live, work or are in transit on Mexico soil, are respected, protected, promoted and guaranteed. During the last years, federal authorities have contemplated strategies that safeguard the Central American migrants' human rights as they travel through Mexico in their development plans, arguing that although there have been advances, there is still much left to do to turn theory into practice. Pubic functionaries need to actively participate as well as the public citizenry to take an active role in respecting the human rights of this vulnerable population. 


\section{Development}

\subsection{Foreign Population in Mexico in Figures}

To talk about foreigners in Mexico turns this study into the context of an international migratory context, which implies the process of changing residence and consequently, the changing of country. (Note 1) Today, governments view migration as a central theme in a public agenda, (Note 2) especially in countries with a high occurrence of migration considering those that are principally on the receiving end of migration, and of course, those countries which are countries in transit, in this case, Mexico, where an infinite number of Central American migrants travel on route towards the United States of America.

According to the results of the 2010 results of the Population and Living Census, today in Mexico, 961,121 people who were born in other countries live in Mexico. This figure represents $0.9 \%$ of the whole population, and this figure is double the number when compared to the figure reported in the census from 2000 , in which 492,617 foreigners were counted living in the country. (Note 3)

Foreign immigrants are found all over Mexican territory, with the largest concentration found in the states of Baja California, Chihuahua, Tamaulipas, Jalisco, Distrito Federal, and Sonora (Note 4). The presence of foreign immigrants has had effects not only in the demographics of the country but also in the social and economical sectors as well.

The foreign population in Mexico comes principally from the United States, Guatemala and Spain and foreign immigrants from Colombia, Argentina, Cuba, Honduras and Venezuela also maintain an important presence. (Note 5) The Central American countries from which most immigrants come from are Guatemala and Honduras, and recently El Salvador, and most of these immigrants constitute an irregular migratory population which transits through Mexico to the United States.

At the end of the decade of the 1970's these countries, together with Nicaragua, lived an era of economic, political and social crisis, which started to conform a new pattern of intense population flow in Central America. In the 1980's, with armed conflicts in many Central American countries, more than a million people emigrated towards other countries, principally to Belize and Mexico. (Note 6)

The situation of undocumented immigrants has not helped to favorably characterize these groups, and there are few figures that show that Central American migrants possess an intermediate level of schooling and work capacity, allowing them to work in semi-qualified activities, occupy intermediate positions in the job market, and even have access to superior income levels than Mexican migrants and those from other countries once they arrive in the United States, which for most of them is their principal destination.

The critical cause of these figures may follow the critical economical situation prevalent in wide sectors of Central American countries, where rural subsistence activities dominate the scene adding to the vulnerability of natural disasters, according to the Economic Commission for Latin America and the Caribbean (CEPAL). This commission has reported that a great part of important and sustainable natural resources have been destroyed in general, affecting basic and traditional sources of sustenance. (Note 7)

This implies that fundamental macrostructures have caused the emigrational wave of Central America, whose population no longer finds jobs nor economic opportunities, and thus decides to abandon the homeland in order to find a place in countries where favorable conditions exist for subsistence. As one of the counties cataloged in an international level as an important pole of attraction, the United States remains an important magnet for the Central American work force.

The Central American migration to Mexico, the object of this study, has been for the most part one of 'in transit' and thus temporal, presenting a considerable percentage of undocumented immigrants (Note 8) who travel through Mexico on their way toward the United States in search of the 'American dream.'

The geographical nearness of the United States, the cultural practice of first generations born in North American territory, the US governmental support given to South American exiles to establish new lives in the center of the country and the porosity of the border between Mexico and Guatemala have been determining factors in the Central American immigration (Note 9) towards the northern neighbor.

\subsection{The Politics of Immigration in Mexico}

The politics toward immigration in Mexico took origin in the necessity to populate the national territory, especially those regions with little population and weak economic activity. This was an 'open door' immigration that did not require mechanisms nor prerequisites to enter the country, but which soon brought about local problems of a sanitary nature which woke up the preoccupations of the authorities. (Note 10) 
These circumstances led the Mexican government to consolidate legislation on migration at the beginning of the twentieth century, with the First General Law of Migration of 1908, in which the immigrant restriction was set out in the following terms: for sickness; for physical and/or mental capacity; minors of 16 years of age who arrive without an accompanying adult; fugitives from justice; those who belong to anarchist societies; beggars and those dependent upon public charity; prostitutes and those who introduce prostitutes to the country for lucrative gain. (Note 11) For the first cases of restrictions, it could be argued that the law was discriminatory.

The Second Law of Migration of 1926, which established that all individuals could immigrate to the country, attending the contained limits in the Political Constitution of Mexico and international treaties, repealed the Law of 1908. The limits determined concerning the entrance into Mexico dealt with knowing how to read and write, drug addicts and drug traffickers, and evidences of a contractual labor relationship in the case of migrant workers. (Note 12)

With this law important advances were made to control immigration, such as the requirement to produce identification for people who entered and left the country, and the expedition of tourist cards to distinguish among those foreigners who were transitory and those who came to live in the country. (Note 13)

The Migrant Law of 1930 in turn repealed this second law, in which the benefit of the entrance of foreigners into the country who were fit, healthy, work-capable, of good conduct and belonged to races easily assimilable in the environment of the country. (Note 14) However, in 1936 the First General Law of the Population was issued. This law changed the course of migratory politics based on the entrance of foreigners into national territory, inclining towards a natural increase in the population instead of a migratory increase. (Note 15)

In 1947, the Second General Law of the Population was issued. This law had similar content concerning the entrance of foreigners into the country. Three decades later, the Third General Law of the Population was issued (1974) through which restricting quotas limited the entrance of immigrants and the need for programs with a better distribution of the population was visualized, considering the possibilities of development in diverse regions of the country based on natural resource potential. (Note 16)

Despite these restrictive instruments derived from the migratory politics of the country, migratory influx continued to increase, most notably in the common border with the United States, which continued to be an attraction for migrants not only from Central and South America, but also for migrants from other continents, such as those from Asia and Africa. (Note 17) These migrants saw Mexico's northern neighbor as an attractive workplace despite the risks that crossing the border implied. These will be analyzed in another article.

\section{Human rights of Central American migrants in Mexico}

\subsection{The Present Situation and Perspectives}

The precarious conditions and the lack of judicial protection are two factors that convert Central American immigrants into a vulnerable population, subject to continuing abuse and violation of human rights by Mexican authorities, private citizens and even by other migrants, who take advantage of social, labor and criminal factors in their situation. (Note 18) As shown above, the illegal situation of Central American migrants turns this population into a highly vulnerable group, even subject to abuses from within their own ranks.

The detention of Central American migrants whas been accompanied by extortion by the authorities before their deportation, along with mistreatment, abuse, and sexual violations committed in the migratory detention centers. This situation is recognized by even the National Commission of Human Rights (CNDH) who point out that ..."irregular migrants are subjected to a situation of clandestinity in which diverse actors, such as business, authorities, tenants, service providers, and even other migrants, contribute to the exploitation and extortion..." (Note 19)

From this, the mistaken attitude of the authorities becomes obvious and is brought into the public eye. Human rights are violated and not limited to wrecking havoc against the migrants from other countries in their own midst in transit to another country, but also reaches the Mexican migrants who are undergoing the same journey to become undocumented workers in the United States. In part, the entire migratory population becomes so weakened that not even the Mexican migrants go to the authorities to ask for protection for their rights with the fear of being deported or escorted back to their place of origin.

Abuses by the authorities have been present in the majority of cases during operations authorized to comply with the General Law of the Population by the National Institute of Immigration (INM). According to the information given by the INM, although no government agent has been fired for violations to human rights, various agents have presented their resignations between 2007 and 2009 due to reiterations of violations caused by them and documented by the CDNH. (Note 20) 
A tangible example of these abuses that was known and attended by the CNDH was a case from March 2008 near the community of The Palms in the municipality of Niltepec in the state of Oaxaca when immigration agents and members of the Marine Corps intercepted a cargo train. According to the CNDH report of 029/2009, migrants who were traveling inside the train were beaten and hurt by immigration agents and Marines who used excessive force, thus causing an investigation to be held. Many other cases have been brought to the attention of the $\mathrm{CNDH}$, and unfortunately for the lack of evidence, have been shelved. (Note 21)

Another constant complaint is extortion. Before the year 2008 irregular migrants were punished with up to 10 years in prison, providing authorities with an easy way to obtain money and commit abuses against undocumented migrants. When the norm changed in 2008, it was hoped that this type of abuse would subside, but extortion continues to be a common practice and serves as a context for other violations to human rights of migrant populations, such as mistreatment, sexual violence and other violations of considerable magnitude. (Note 22)

The CNDH plays an important role as the place to lodge complaints by violated migrants, especially since 1995 with the creation of the Fifth Law for the protection of migrants' rights. Since then with more than 500 cases of abuse, the complaints have intensified and recommendations to the Immigration Service and other governmental offices have been made. (Note 23)

Since the constitutional reform of 2011 (Note 24) which gradually consolidated a state guarantee of human rights, promoting, respecting, protecting and guaranteeing the human rights (Note 25) of all people, including, of course those who are passing through the country as migrants. Effective protection by the State against any violent act against the human rights of the migrant population, whether undocumented or legal, is protected by this reform.

Important advances in favor of human rights protection have been made on the behalf of the migrant population that have been consolidated throughout the country, such as the case of the Beta Groups of the National Immigration Institute, which were formed from the need to assure the well-being and health of the migrants. The general objective of these groups is to provide protection and defense of human rights of migrant workers, as well as physical integrity and health without distinguishing the immigrants' status. According to the INM, this project has provided important results and saved many lives. (Note 26)

Currently, 21 Beta Groups are in operation, made up of members of the three branches of government in nine states of the country: Baja California, Sonora, Chihuahua, Coahuila, Tamaulipas, Veracruz, Tabasco, Chiapas, and Oaxaca. Of noteworthy mention is that part of the training of these groups can be found in the basic knowledge of human rights. (Note 27) It is hoped that the multiplying effect of this type of actions and more and better alternatives have been generated in order to safeguard the rights of these people.

Another significant advance made by the Mexican government in migratory matters that should be looked at is the Puebla Process from the Regional Conference on Migration, which has been meeting since 1996 and joining together governmental groups, civil organizations, and in general, societies of countries which are involved in the migratory phenomenon. One of the central tenets of the conference is the protection of human rights of migrants and their families. (Note 28) What stands out in in this experience is the participation of the local citizens, which in a bigger plane implies that not only the government needs to be respectful of human rights, but also the local citizenry.

Facing the gravity of the Central American migration theme, the National Development Plan of 2012 marked the importance of maintaining an active and responsible policy, the imminent necessity to protect all Latin Americans who enter the country, who in their majority are undocumented and live in conditions of extreme insecurity and judicial uncertainty, all in the framework of a new culture of migration in five strategies:

a) Respect and protect the human rights of migrants in Mexico: seek to organize the respect and protection of human rights of migrants from other countries on Mexican territory and stimulate temporal employment in zones that can absorb labor and the concurrence in Guatemala to establish a similar program in the neighboring country;

b) Promote a vision of co-responsibility in which Mexico generates better opportunities of development in national territory

c) Promote the productive investment of capital in regions which produce labor through mechanisms of bilateral and regional cooperation to boost development in disadvantaged zones as well as in countries in Central America, from where the great part of undocumented workers come

d) Contribute toward generating opportunities in Mesoamerica, to generate jobs which aimed to provide Central Americans the possibility of remaining in their countries and 
e) Better the quality of the services and migratory services in general, where the modernization of the infrastructure, especially of migratory stations and combating against corruption. (Note 29)

The strategies that are tied in with the investment of productive capital and temporary jobs fall into what Manuel Angel Castillo names actions that focus on the cause and not on the symptom of the process, (Note 30) and can be said to be the ideal path for the solution of a problem, but which will with difficulty take place given the economic conditions of the expulsing countries, such as is the case of Mexico.

Regarding the protection and guarantee of the human rights of Central American migrants in Mexico, with reference to constitutional Reform of 2011 and the ratification of international treaties concerning human rights, it can be hoped that governmental and public policies are finally concerning themselves with the rights of these vulnerable groups. Mexico today is under the magnifying glass of international organisms and thus the actions taken for human rights should be on the rise, thus suppressing the measures taken against those who are the most vulnerable.

In Mexico, although work has begun toward this end, the path ahead is complex, so the combined effort of the authorities, non-governmental organizations and the civilian society of the country, the countries from which the migrants come, and the countries which receive them will have to participate in the formulation of an integral public policy in order to permit a dignified stay or transit of the migrant population and an effective respect, promotion, protection and guarantee of their human rights.

\section{Conclusions}

Central American migration to Mexico has been constant since the 1920's, has consolidated during the 1990's and since around the year 2000, has increased greatly despite the limitations in place of the Mexican migration laws.

The conditions which Central American migrants in Mexico present are that the majority are undocumented or irregular which makes them vulnerable to the violation of their human rights against their physical and psychological health by the Mexican authorities, Mexican citizenry, the migrants themselves, and society in general.

The National Commission of Human Rights has play a fundamental role in promoting respect toward this weakened population; however, an important amount of the complaints lodged in the Commission have been shelved given the lack of proof or evidence, leaving the migrant population defenseless and without lawful recourse.

With the constitutional reform of 2011, it is hoped that effective protection of human rights by the Mexican government will be offered to promote, respect, investigate, sanction, and repair the violations of human rights, thus endorsing the commitments underlined by the country in international treaties.

However, these lawful modifications have not been sufficient to protect the migrant population; there also needs to be set into place integral migratory policies that involve the authorities of different levels of government, non-government organizations, and the civilian society of the country where migrants travel toward, countries through which they travel, and the countries which they leave in order to obtain an effective respect, protection and guarantee of the human rights of the migrant population.

Therefore, it is necessary to implement a series of actions that provide incentive to denounce the violation of human rights to migrants, in order to obtain security and confidence of the vulnerable population to guarantee protection of their rights.

\section{Recommendations}

The Central American migrant population has scarcely been studied, and needs quantitative and qualitative investigative methodology with valid and reliable instruments which permit real information and knowledge about these groups in multiple determinants (age, sex, civil state, educational level, occupation, level of income, etc.) in order to study further the situation and construct theories of primordial axis of action.

Furthermore, strategies that permit the documentation of the central problem which this population is confronting during its stay in Mexico, of the governmental politics that are practiced upon the same population, that are implemented with respect, protection and guarantee of their human rights, safeguarding their physical and psychological health. These same politics need to involve the Mexican society to uphold the dynamic of respect of the migrants' human rights. 


\section{References}

Academia Mexicana De Derechos Humanos. (2011). Boletín Informativo Ombudsman Ciudadano [versión electrónica], No, 21, Año 4, México, Academia Mexicana de Derechos Humanos. Retrieved from http://132.247.1.49/vigia_ciudadano/images/boletines/21_boletin_cndh_inv.pdf

Amnistía Internacional. (2010). Víctimas Invisibles Migrantes en Movimiento en México [versión electrónica]. España, Editorial Amnistía Internacional. Retrieved from http://www.amnesty.org/es/library/asset/AMR41/ 014/2010/en/1345cec1-2d36-4da6-b9c0-e607e408b203/amr410142010es.pdf

Ángel Castillo, M. (2000). Las Políticas hacia la Migración Centroamericana en Países de Origen, de Destino y de Tránsito. Papeles de Población [versión electrónica] (pp. 133-157). México, Universidad Autónoma del Estado de México. Retrieved from http://www.oecd.org/dev/pgd/43082430.pdf

Arámbula Reyes. (2007). Alma, El Flujo Migratorio Centroamericano a México [versión electrónica]. México, Centro de Documentación, Información y Análisis de la Cámara de Diputados. Retrieved from http://biblio.juridicas.unam.mx/libros/6/2992/7.pdf

Argüello Zepeda. Francisco J. (2005). Derechos Humanos de Mujeres Migrantes del Medio Rural en México. Migración y Derechos Humanos, 8. Certamen de Ensayo sobre Derechos Humanos (en línea, No. 1, pp. 83-90). Retrieved from http://www.codhem.org.mx/LocalUser/codhem.org/difus/ensayo/8En.pdf

Carbonell, M. (2011). Las Obligaciones del Estado en el Artículo $1^{\circ}$. de la Constitución Mexicana. La Reforma Constitucional de Derechos Humanos. Un Nuevo Paradigma (p. 449). CARBONELL, Miguel y SALAZAR, Pedro (Coordinadores) México, Instituto de Investigaciones Jurídicas de la UNAM.

Instituto Nacional De Estadística Y Geografía. Conociendo...nos todos. Informativo Oportuno [versión electrónica], 1(2), 4. México, Instituto Nacional de Estadística y Geografía. Retrieved from www.inegi.org.mx/inegi/contenidos/espanol/.../nacidosenotropais.pdf

Instituto Nacional De Migración. Grupos Beta del INM [versión electrónica], México, Instituto Nacional de Migración, [s.a.], [s.p.]. Retrieved from http://www.inm.gob.mx/index.php/page/Grupo_Beta

Los Extranjeros en México [versión electrónica]. México, Instituto Nacional de Estadística y Geografía, [s.a.]. Retrieved from http://www.inegi.gob.mx/prod_serv/contenidos/espanol/bvinegi/productos/estudios/ sociodemografico/ext_en_mex/extraen_mex.pdf

Presidencia De La República. (2007). Plan Nacional de Desarrollo 2007-2012 [versión electrónica] (p. 324). Retrieved from http://pnd.calderon.presidencia.gob.mx/pdf/Eje5_Democracia_Efectiva_y_Politica _Exterior_Responsable/5_9_Mexicanos_en_el_Exterior_y_Migracion.pdf

Pries, Ludger. (2002). La Migración Transnacional y la Perforación de los Contenedores de Estados-Nación Estudios Demográficos y Urbanos [en línea], 51, 571-597. Retrieved from http://redalyc.uaemex.mx/redalyc/pdf/312/31205105.pdf

Yankelevich, Pablo y Chenillo Alazraki, Paola. (2008). El Archivo Histórico del Instituto Nacional de Migración. Desacatos [versión electrónica], Núm. 26, México, Centro de Investigación y Estudios Superiores en Antropología Social, pp. 25-42. Retrieved from http://redalyc.uaemex.mx/pdf/139/13902603.pdf

\section{Legislativas}

Constitución Política de los Estados Unidos Mexicanos

\section{Notes}

Note 1. Ludger Pries, "La Migración Transnacional y la Perforación de los Contenedores de Estados-Nación", in: Estudios Demográficos y Urbanos [on line], México, No. 51, 2002, p.581.

Note 2. Francisco J. Argüello Zepeda, "Derechos Humanos de Mujeres Migrantes del Medio Rural en México", Migración y Derechos Humanos, $8^{\circ}$. Certamen de Ensayo sobre Derechos Humanos [on line], México, No. 1, 2005, p. 86.

Note 3. INSTITUTO NACIONAL DE ESTADÍSTICA Y GEOGRAFÍA, “Conociendo...nos todos", en: Informativo Oportuno [on line], Vol. I, Núm. 2, México, Instituto Nacional de Estadística y Geografía, 2011, p.1

Note 4. INSTITUTO NACIONAL DE ESTADÍSTICA Y GEOGRAFÍA, "Conociendo...nos todos", en: Informativo Oportuno [on line], Vol. I, Núm. 2, México, Instituto Nacional de Estadística y Geografía, 2011, p.1. 
Note 5. INSTITUTO NACIONAL DE ESTADÍSTICA Y GEOGRAFÍA, "Conociendo...nos todos", en: Informativo Oportuno [on line], Vol. I, Núm. 2, México, Instituto Nacional de Estadística y Geografía, 2011, p.1.

Note 6. ÁNGEL CASTILLO, Manuel, "Las Políticas hacia la Migración Centroamericana en Países de Origen, de Destino y de Tránsito", en: Papeles de Población [versión electrónica], México, Universidad Autónoma del Estado de México, 2000, pp. 133-134.

Note 7. ÁNGEL CASTILLO, Manuel, Op. Cit., p. 136.

Note 8 . In 2004, 1.4 million people entered the country illegally, while 204,000 entered without documents; most of these were Central Americans.

Note 9. Ibidem, p. 25.

Note 10. YANKELEVICH, Pablo y Chenillo Alazraki, Paola, "El Archivo Histórico del Instituto Nacional de Migración" en: Desacatos [versión electrónica], Núm. 26, México, Centro de Investigación y Estudios Superiores en Antropología Social, 2008, p. 30. The sanitary problem derived from Asian immigrants who carried with them such infectious diseases as the bubonic plague, cholera, beriberi and trachoma.

Note 11. YANKELEVICH, Pablo y Chenillo Alazraki, Paola, "El Archivo Histórico del Instituto Nacional de Migración", p. 31

Note 12. YANKELEVICH, Pablo y Chenillo Alazraki, Paola, "El Archivo Histórico del Instituto Nacional de Migración", p. 31.

Note 13. INSTITUTO NACIONAL DE ESTADÍSTICA Y GEOGRAFÍA, Los Extranjeros en México, p.3.

Note 14. YANKELEVICH, Pablo y Chenillo Alazraki, Paola, "El Archivo Histórico del Instituto Nacional de Migración", p.33.

Note 15. INSTITUTO NACIONAL DE ESTADÍSTICA Y GEOGRAFÍA, Los Extranjeros en México, p.4.

Note 16. YANKELEVICH, Pablo y Chenillo Alazraki, Paola, "El Archivo Histórico del Instituto Nacional de Migración", p. 35.

Note 17. INSTITUTO NACIONAL DE ESTADÍSTICA Y GEOGRAFÍA, Los Extranjeros en México, p.4.

Note 18. ARÁMBULA REYES, Alma, El Flujo Migratorio Centroamericano a México [versión electrónica], México, Centro de Documentación, Información y Análisis de la Cámara de Diputados, 2007, p. 9.

Note 19. COMISIÓN NACIONAL DE DERECHOS HUMANOS, Cit. por ARÁMBULA REYES, Alma, $O p$. Cit., p. 10.

Note 20. AMNISTÍA INTERNACIONAL, Victimas Invisibles Migrantes en Movimiento en México [on line], España, Editorial Amnistía Internacional, 2010, p. 21.

Note 21. AMNISTÍA INTERNACIONAL, Op. Cit., p. 21.

Note 22. Ibidem, p. 25

Note 23. Ibidem, p. 31.

Note 24. ACADEMIA MEXICANA DE DERECHOS HUMANOS, Boletín Informativo Ombudsman Ciudadano [on line], No, 21, Año 4, México, Academia Mexicana de Derechos Humanos, 2011, p. 3.

Note 25. CARBONELL, Miguel, "Las Obligaciones del Estado en el Artículo $1^{\circ}$. de la Constitución Mexicana", en: La Reforma Constitucional de Derechos Humanos. Un Nuevo Paradigma, CARBONELL, Miguel y SALAZAR, Pedro (Coordinadores) México, Instituto de Investigaciones Jurídicas de la UNAM, 2011, p. 64.

Note 26. INSTITUTO NACIONAL DE MIGRACIÓN, Grupos Beta del INM [versión electrónica], México, Instituto Nacional de Migración, [s.a.], [s.p.].

Note 27. Ibidem

Note 28. ÁNGEL CASTILLO, Manuel, Op. Cit., p. 149.

Note 29. PRESIDENCIA DE LA REPÚBLICA, Plan Nacional de Desarrollo 2007-2012 [versión electrónica], México, 2007, pp. 307-309.

Note 30. ÁNGEL CASTILLO, Manuel, Op. Cit., p. 149. 


\section{Copyrights}

Copyright for this article is retained by the author(s), with first publication rights granted to the journal.

This is an open-access article distributed under the terms and conditions of the Creative Commons Attribution license (http://creativecommons.org/licenses/by/3.0/). 